\title{
Bemisia afer sensu lato, a Vector of Sweet potato chlorotic stunt virus
}

Heidy A. Gamarra and Segundo Fuentes, International Potato Center, La Molina, Lima, Peru; Francisco J. Morales, International Center for Tropical Agriculture, Cali, Colombia; Rachel Glover and Chris Malumphy, The Food and Environment Research Agency, Sand Hutton, York, UK; and Ian Barker, International Potato Center, Lima, Peru

\begin{abstract}
Gamarra, H. A., Fuentes, S., Morales, F. J., Glover, R., Malumphy, C., and Barker, I. 2010. Bemisia afer sensu lato, a vector of Sweet potato chlorotic stunt virus. Plant Dis. 94:510-514.

Bemisia tabaci biotype B is considered to be the primary vector of Sweet potato chlorotic stunt virus (SPCSV, Crinivirus). However, Trialeurodes abutiloneus also has been shown to transmit SPCSV in a semipersistent manner. Mixed infection of SPCSV with the aphid-transmitted Sweet potato feathery mottle virus (SPFMV, Potyvirus) causes sweetpotato (Ipomoea batatas) virus disease (SPVD), the major virus disease affecting this crop. High populations of $B$. afer sensu lato are seasonally associated with sweetpotato in Peru during times of low B. tabaci incidence. The transmission of SPCSV (in single and double infection with SPFMV) by laboratory-reared B. afer sensu lato and B. tabaci biotype B was investigated. For SPCSV transmission efficiency, individual adult insects were allowed $48 \mathrm{~h}$ for acquisition and inoculation access periods at both 20 and $25^{\circ} \mathrm{C}$. SPCSV was transmitted by both whiteflies, with similar transmission efficiency when the virus was acquired from plants singly infected by SPCSV or doubly infected with SPCSV and SPFMV, at 20 and $25^{\circ} \mathrm{C}$. We conclude that $B$. afer sensu lato is a newly identified vector of SPCSV. This finding may have important epidemiological significance for the spread of SPCSV and SPVD.
\end{abstract}

Sweet potato chlorotic stunt virus (SPCSV) is a Crinivirus sp. (family Closteroviridae) transmitted by Bemisia tabaci (Gennadius) and Trialeurodes abutiloneus Haldeman (Hemiptera: Aleyrodidae) (21) in a semipersistent manner $(4,10,27,34$, 40,44,45). SPCSV is the most important virus affecting sweetpotato (Ipomoea batatas (L.) Lam.) due to its ability to mediate severe synergistic diseases with several other sweetpotato-infecting viruses belonging to different genera $(14,15,26,39)$. SPCSV, together with the aphid-borne Potyvirus sp. Sweet potato feathery mottle virus (SPFMV; family Potyviridae), are the causal agents of sweetpotato virus disease (SPVD), the main viral disease affecting this crop in different regions of the world $(11,14,29,38)$. Sweetpotato yield reductions caused by SPCSV are approximately $30 \%$ but can exceed $50 \%$ when interacting with other viruses $(11,17)$.

B. afer (Priesner \& Hosny) $(3,6)$ sensu lato occurs in Africa, Australia, the Mediterranean coast of Europe, southern England, and South America $(3,18,20)$. This whitefly species was first reported in the Americas in Peru on sweetpotato in 2000 (3). B. afer infests plants in the families Anacardiaceae, Annonaceae, Apocyna-

Corresponding author: S. Fuentes

E-mail: s.fuentes@cgiar.org

Accepted for publication 10 January 2010.

doi:10.1094/PDIS-94-5-0510

(c) 2010 The American Phytopathological Society ceae, Bignoniaceae, Bixaceae, Bombacaceae, Burseraceae, Celastraceae, Caprifoliaceae, Combretaceae, Convolvulaceae, Euphorbiaceae, Fabaceae, Labiateae, Liliaceae, Loganiaceae, Lythraceae, Malvaceae, Moraceae, Myrtaceae, Papaveraceae, Rhamnaceae, Rosaceae, Rubiaceae, Rutaceae, Salicaceae, Sapindaceae, Solanaceae, and Urticaceae $(3,5,16,20,24)$.

B. afer and SPCSV have been previously reported together in Peru, Uganda, Kenya, Tanzania, Madagascar, Nigeria, Egypt, and Spain $(3,11,17)$. Although Crinivirus spp. are unique among whiteflyvectored viruses in that members of different genera of whiteflies can transmit them, B. tabaci biotype B is the only Bemisia sp. identified as a vector of SPCSV to date. The possibility that $B$. afer sensu lato is a vector for this virus is particularly relevant because this species of whitefly colonizes sweetpotato at high levels. The importance of B. afer sensu lato as a vector of sweetpotato viruses (or any other plant viruses) has never been documented.

In this study, we describe, for the first time, transmission of SPCSV by $B$. afer sensu lato, the effect of temperature on the transmission of SPCSV in single and double infections with SPFMV, and the epidemiological implications associated with efficient transmission of SPCSV by both B. afer sensu lato and B. tabaci biotype B.

\section{MATERIALS AND METHODS}

Plant material and virus isolates. Virus-free sweetpotato cv. Costanero plants, determined by indexing them through grafting to I. setosa Ker with subsequent serological tests, were provided by the International Potato Center (CIP, Lima, Peru). Virus-free plants of I. nil (L.) Roth were grown from botanical seed, because no sweetpotato virus reported so far is seed transmitted. In addition, random samples were tested by enzyme-linked immunosorbent assay on nitrocellulose membranes (NCM-ELISA) (11) to confirm freedom from SPCSV and SPFMV. Hereafter, virus-free plants are referred to as "healthy plants."

SPCSV isolate M2-47, belonging to the East African (EA) strain (11), was obtained from infected sweetpotato plants collected in the Valley of Cañete, Peru, using $B$. tabaci biotype B as vector on I. nil.

The russet crack strain of SPFMV (U.S. isolate) was obtained from the CIP virus collection and maintained in I. nil by mechanical inoculation.

Healthy sweetpotato plants were sidegraft inoculated with SPCSV (single infection) and with both SPCSV and SPFMV (double infection) to yield virus sources for transmission studies.

Whitefly colonies and species identification. CIP colonies of B. afer sensu lato and $B$. tabaci biotype B were established from the pupal stage obtained from sweetpotato plants growing in the Valley of Cañete, Lima, Peru. The whiteflies were mass-reared on healthy sweetpotato cv. Costanero plants. The third generation was used to obtain whitefly colonies of the same age. Identification of the whitefly species was confirmed morphologically from the puparia (Fig. 1) $(20,30)$ in two different laboratories: the International Center for Tropical Agriculture (CIAT), Colombia and The Food and Environment Research Agency (FERA), UK. The two whitefly species were also differentiated by amplification and sequencing of a fragment of the mitochondrial 16S rDNA gene, obtained by polymerase chain reaction (PCR) at CIAT-Colombia. Universal primers 4118 (CCGGTCTGAACTCAG ATCACGY) and 4119 (CGCCTGTTT AACAAAAACAT), constructed for the mitochondrial 16S rDNA gene of Drosophila yakuba, were used in the PCR reactions according to Xiong and Kocher (46) and modified by Calvert et al. (8).

For B. afer sensu lato, the mitochondrial 16S rDNA fragment obtained by PCR was sequenced and compared with that published in the GenBank database for $B$. leakii Peal (AF247531); B. hancocki Corbett (AF247532); B. tabaci biotypes B, Q, 
and S (AF246636, AF246647, and AF247527, respectively); B. tabaci biotypes collection (AF110722, AF110714, AF110713, AF110715, AF110716, AF110717, AF110719, and AF110721), $T$. vaporariorum Westwood (AF110723); Al-

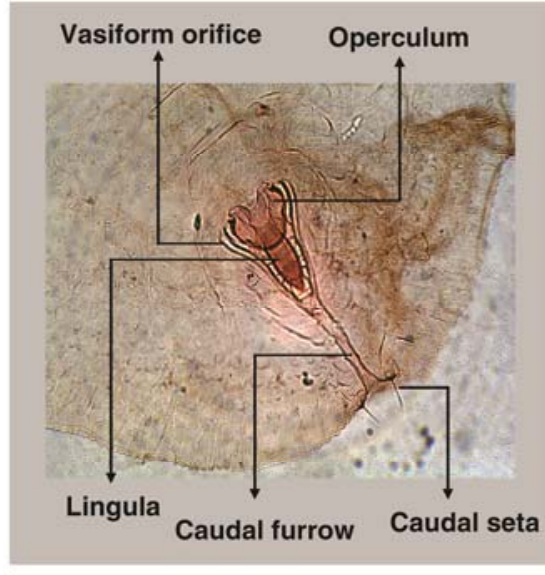

Morphological Bemisia afer character

Caudal setae Always less than half the length of the vasiform orifice and often minute; highly variable among individuals

Vasiform orifice Usually shorter than length of the caudal furrow, with sides often distinctly concave. The surface of vasiforme orifice underneath lingula is reticuled. The vasiform orifice is concave

Lingula Long and narrow

Caudal furrow

Similar in length to the vasiform orifice

Operculum

The operculum is triangular in shape europlatus coronata Quaintance (EU471164); and those unpublished provided by CIAT for B. tabaci biotype A, B. tuberculata Bondar, T. vaporariorum, T. variabilis Quaintance, and Aleurotrachelus socialis Bondar (8). The alignments and phyloge-

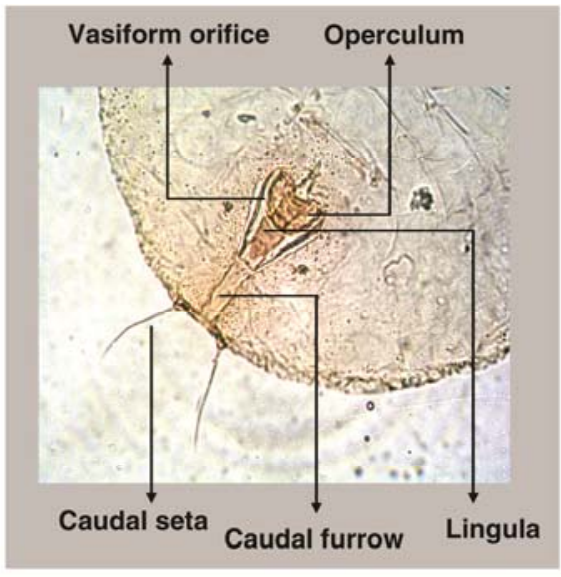

Bemisia tabaci biotype B

Always stout and usually as long or longer than vasiform orifice. Little variation among individuals

Slightly longer than the length of the caudal furrow, with straight sides. The surface of vasiforme orifice underneath lingula in $B$. tabaci is not reticulated compared with $B$. afer. The orifice is triangular in shape.

Shorter and slightly wider than in B. afer

Slightly shorter than the length of the vasiform orifice

The operculum is oval in shape netic analysis were performed with the MEGA 4 software package (37). Distances were calculated using the Kimura twoparameter model, and a tree was assembled using neighbor joining with 2,000 bootstrap replicates.

Virus transmission. Completely randomized experimental design was set up as a $2^{3}$ factorial (two whitefly species, two temperatures, and two virus sources) in four replications with 25 plants per experimental unit (Table 1). Adult whiteflies from the third generation of $B$. afer sensu lato and $B$. tabaci biotype $\mathrm{B}$ were used as vectors in the virus transmission efficiency tests. Individual whitefly adults were allowed an acquisition access period (AAP) of $48 \mathrm{~h}$ on sweetpotato plants infected with SPCSV and with both SPCSV and SPFMV. Single viruliferous whiteflies were then placed on individual healthy $I$. nil plants (test plants) for an inoculation access period (IAP) of $48 \mathrm{~h}$ (Table 1). Acquisition and inoculation periods were carried out at both 20 and $25^{\circ} \mathrm{C}$ in a growth chamber (temperature controlled, with $3,500 \mathrm{~lx}$ per $12 \mathrm{~h}$ of fluorescent and bulb lights).

Five infected $I$. batatas plants with high levels of SPCSV (from single and double infection with SPFMV), as determined by NCM-ELISA (11), were selected as virus sources. At the end of each IAP, whiteflies were removed manually and plants were sprayed with $1 \%$ buprofezin. Inoculated $I$. nil plants were maintained in an insectproof greenhouse at 10,000 to $15,000 \mathrm{~lx}$ light intensity for evaluation. Number of infected plants was recorded and transmission efficiency was analyzed by the test of equal or given proportions using the R Statistical program (31). For interaction studies, normality of data was corrected through angular transformation, which allowed performance of analysis of variance.

Virus detection. Test plants were evaluated beginning 2 weeks after inoculation and monitored for 60 days. SPCSV infection was initially detected by symptom expression in the inoculated plants at 10 to 20 days after inoculation. All symptomatic

Fig. 1. Comparison of some morphological characters of Bemisia tabaci biotype B and B. afer sensu lato puparia, used for taxonomic identification. Top, photographs of the posterior of the puparia. Bottom, descriptions of morphological characters of the puparia.

Table 1. Transmission efficiency of Sweet potato chlorotic stunt virus (SPCSV) with individual adults of Bemisia afer sensu lato and B. tabaci biotype B at two temperatures, using sweetpotato (Ipomoea batatas) cv. Costanero plants infected with SPCSV (single infection) and with SPCSV and Sweet potato feathery mottle virus (SPFMV) (double infection) as virus source plant and Ipomoea nil as test plant

\begin{tabular}{|c|c|c|c|c|c|c|c|c|c|c|c|c|c|c|}
\hline \multirow[b]{4}{*}{ Whitefly, virus source } & \multicolumn{14}{|c|}{ Temperature } \\
\hline & \multicolumn{7}{|c|}{$20^{\circ} \mathrm{C}$} & \multicolumn{7}{|c|}{$25^{\circ} \mathrm{C}$} \\
\hline & \multicolumn{4}{|c|}{ Replications $^{\mathbf{a}}$} & \multirow[b]{2}{*}{$\mathbf{E}(\%)^{\mathbf{b}}$} & \multirow[b]{2}{*}{ STD $^{c}$} & \multirow[b]{2}{*}{$\mathbf{S E}^{\mathbf{d}}$} & \multicolumn{4}{|c|}{ Replications $^{\text {a }}$} & \multirow[b]{2}{*}{$\mathbf{E}(\%)^{\mathbf{b}}$} & \multirow[b]{2}{*}{ STD $^{\mathrm{c}}$} & \multirow[b]{2}{*}{$\mathbf{S E}^{\mathrm{d}}$} \\
\hline & 1 & 2 & 3 & 4 & & & & 1 & 2 & 3 & 4 & & & \\
\hline \multicolumn{15}{|l|}{ B. afer sensu lato } \\
\hline SPCSV & $3 / 23$ & $2 / 25$ & $2 / 25$ & $4 / 25$ & 11.2 & 0.96 & 0.24 & $4 / 25$ & $2 / 25$ & $2 / 25$ & $5 / 25$ & 13 & 1.5 & 0.38 \\
\hline SPCSV+SPFMV & $1 / 25$ & $3 / 24$ & $2 / 25$ & $4 / 25$ & 10.1 & 1.29 & 0.32 & $1 / 25$ & $2 / 25$ & $3 / 24$ & $1 / 25$ & 6.1 & 0.96 & 0.24 \\
\hline \multicolumn{15}{|l|}{ B. tabaci biotype B } \\
\hline SPCSV & $4 / 25$ & $2 / 25$ & $0 / 25$ & $1 / 25$ & 7 & 1.71 & 0.46 & $3 / 25$ & $2 / 25$ & $0 / 25$ & $3 / 25$ & 8 & 1.41 & 0.35 \\
\hline SPCSV+SPFMV & $2 / 25$ & $4 / 25$ & $4 / 24$ & $3 / 25$ & 13.1 & 0.96 & 0.24 & $2 / 24$ & $6 / 25$ & $0 / 25$ & $4 / 25$ & 12.1 & 2.58 & 0.65 \\
\hline
\end{tabular}

a Number of infected plants/number of total inoculated plant (experimental unit) per each replication.

${ }^{\mathrm{b}}$ Percentage of total infected plants from total inoculated plants.

${ }^{c}$ STD $=$ standard deviation.

${ }^{\mathrm{d}} \mathrm{SE}=$ standard error. 
and nonsymptomatic plants were tested by NCM-ELISA (11) or by reverse-transcription (RT)-PCR) periodically throughout the 60 days. Primers CP1 (CGTCTAGATTGTTAGAAA) and CP3 (AACGCG GAAGTGTAAGGTAT) were used in the RT-PCR reactions according to Alicai et al. (2). Total nucleic acids were extracted from plants prior to RT-PCR using Plant RNA Purification Reagent (Invitrogen, CA).

\section{RESULTS}

Identification of whiteflies species. Both species of Bemisia were identified by the morphological characters observed on puparia, according to the key features shown in Figure 1. Pupae of B. afer sensu lato are larger and are transparent or slightly yellowish compared with those of B. tabaci. Important diagnostic characteristics of $B$. afer sensu lato include short caudal setae, vasiform orifice subequal in length to caudal furrow, and lingual head long and narrow with triangular operculum (Fig. 1). The CIP colony was confirmed as B. afer sensu lato by whitefly taxonomists P. Hernandez at CIAT and C. Malumphy at FERA. A 529-bp PCR product amplified from the mitochondrial 16S rDNA was obtained from $B$. afer samples. Phyloge-
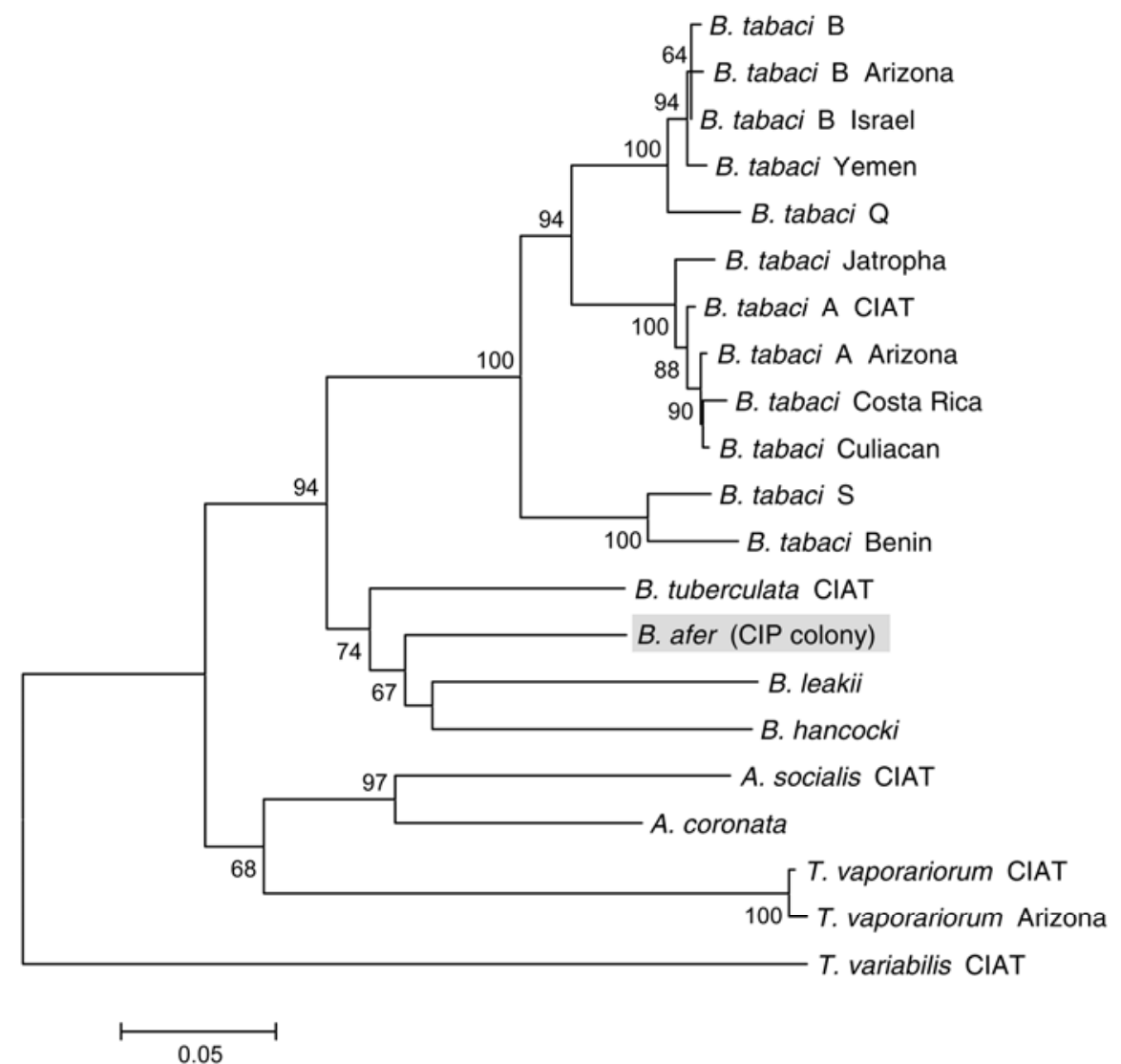

Fig. 2. Phylogenetic tree calculated from alignments of nucleotide sequences on the mitochondrial $16 \mathrm{~S}$ rDNA gene of Bemisia afer sensu lato (GenBank accession no. FJ969473) with other whitefly species. Percentage of bootstrap support out of 2,000 replicates is given at each of the major nodes in the tree. Scale bar indicates Kimura nucleotide distances.

netic analysis of the $B$. afer sensu lato nucleotide sequence (GenBank accession no. FJ969473) indicated a relatively close relationship to $B$. tuberculata, B. leakii, and $B$. hancocki $(84.1,82.8$, and $81.9 \%$ identity, respectively) (Fig. 2).

Virus transmission. All plants exhibiting symptoms of SPCSV tested positive for SPCSV by NCM-ELISA and RT-PCR, and all symptomless plants tested negative. SPCSV was transmitted at a low level by individual whiteflies of both $B$. afer sensu lato $(6.1$ to $13 \%)$ and B. tabaci biotype B (7 to $13.1 \%$ ) when the virus was acquired from singly or doubly infected $I$. batatas plants (Table 1). The transmission rate of the virus was higher when transmitted by $B$. afer sensu lato from singly than doubly infected plants, with this difference being more evident at 25 than at $20^{\circ} \mathrm{C}$ (Table 1). The contrary occurred with $B$. tabaci biotype $B$, with an apparent increased rate of transmission from doubly infected plants at both temperatures (Table 1). However, none of these differences are statistically significant (Table 2). Both whitefly species transmitted the virus with similar transmission efficiency because they did not differ significantly in their transmission rate when SPCSV was acquired from singly infected or doubly infected plants or when comparing both virus-infected sources plants at both temperatures (Table 2).

The interaction between whitefly species and virus sources was moderately significant $(P$ value $=0.09)$ in spite of a relatively high variation coefficient of $43 \%$.

\section{DISCUSSION}

Knowing the existence of new virus vectors is important for plant disease management. This study provides experimental data showing that, in addition to $B$. tabaci and $T$. abutiloneus, SPCSV can also be transmitted by the whitefly species $B$. afer sensu lato. To our knowledge, this is the first time that $B$. afer sensu lato has been reported as a virus vector. Previous studies by Maruthi et al. (22) reported that B. afer sensu lato was not able to transmit the Ipomovirus sp. Cassava brown streak virus, even though the disease seemed asso-

Table 2. Statistical analysis by the test of equal or given proportion ( $n=98$ to 100) of the transmission of Sweet potato chlorotic stunt virus (SPCSV) from two virus sources by two whitefly species at two temperatures, using the R Statistical program (31)

\begin{tabular}{|c|c|c|c|c|c|c|c|c|}
\hline \multirow[b]{2}{*}{ Comparison of } & \multicolumn{2}{|c|}{ at $20^{\circ} \mathrm{C}$} & \multicolumn{2}{|c|}{ at $25^{\circ} \mathrm{C}$} & \multicolumn{2}{|c|}{ B. afer sensu lato } & \multicolumn{2}{|c|}{ B. tabaci biotype B } \\
\hline & $\chi^{2}$ & $P$ value & $\chi^{2}$ & $P$ value & $\chi^{2}$ & $P$ value & $\chi^{2}$ & $P$ value \\
\hline \multicolumn{9}{|l|}{ Virus source for ${ }^{\mathrm{a}}$} \\
\hline B. afer sensu lato & $<0.001$ & 0.98 & 1.33 & 0.25 & $\ldots$ & $\ldots$ & $\ldots$ & $\ldots$ \\
\hline B. tabaci biotype B & 1.47 & 0.23 & 0.53 & 0.46 & $\ldots$ & $\ldots$ & $\ldots$ & $\ldots$ \\
\hline \multicolumn{9}{|l|}{ Vector species from ${ }^{\mathrm{b}}$} \\
\hline SPCSV+SPFMV source & 0.19 & 0.66 & 0.93 & 0.33 & $\ldots$ & $\ldots$ & $\ldots$ & $\ldots$ \\
\hline SPCSV source & 0.62 & 0.46 & 0.85 & 0.36 & $\ldots$ & $\ldots$ & $\ldots$ & $\ldots$ \\
\hline \multicolumn{9}{|l|}{ Temperatures with ${ }^{\mathrm{c}}$} \\
\hline SPCSV+SPFMV source & $\ldots$ & $\ldots$ & $\ldots$ & $\ldots$ & 0.26 & 0.61 & 0.00 & 1.00 \\
\hline SPCSV source & $\ldots$ & $\ldots$ & $\ldots$ & $\ldots$ & 0.03 & 0.87 & 0.00 & 1.00 \\
\hline
\end{tabular}

${ }^{a}$ Comparison of virus source: SPCSV versus Sweet potato feathery mottle virus (SPFMV).

${ }^{\mathrm{b}}$ Comparison of vector species: $B$. afer sensu lato versus $B$. tabaci biotype B.

${ }^{c}$ Comparison of temperatures: 20 versus $25^{\circ} \mathrm{C}$. 
ciated with this species in the field. In the study presented herein, transmission of SPCSV was achieved by both $B$. afer sensu lato and B. tabaci biotype B. The transmission of SPCSV by individual adults of $B$. afer sensu lato suggests that this insect is a relatively efficient vector of SPCSV. Wintermantel and Wisler (42) observed that only the most efficient vectors were capable of transmitting the closely related Crinivirus sp. Tomato chlorosis virus (ToCV) by individual whiteflies. It has been also observed that transmission efficiency of the Crinivirus spp. ToCV and Lettuce infectious yellows virus are influenced by the number of individuals used to inoculate test plants $(27,28,42)$. Obviously, the number of whitefly individuals found on plants under field conditions greatly exceeds the highest numbers of whitefly individuals tested under experimental conditions.

It seems possible that whiteflies might acquire the virus more readily from hosts other than sweetpotato (33). AAP and IAP of $48 \mathrm{~h}$, fairly typical for Crinivirus spp., have been shown to work well for transmission of SPCSV $(34,40)$. In this study, the transmission of SPCSV by single whiteflies of both $B$. afer sensu lato and $B$. tabaci biotype B was low from infected sweetpotato plants. It was reported that transmission efficiency of sweetpotato viruses increases when a larger number of whiteflies (more than 15) $(12,32,33)$ are used per plant and when infected plants other than sweetpotato are used as the virus source.

Distinct isolates of SPCSV have been reported from different geographical regions $(1,9,13,36)$. These isolates form two groups according to their serological and molecular relationship: the EA and the non-EA strains. B. tabaci biotype B is able to transmit SPCSV isolates from EA (this study) and non-EA (34) strains with similar efficiency. In both cases, transmission experiments were carried out using similar conditions: virus was acquired from SPVD-infected (SPCSV+SPFMV) sweetpotato by single whiteflies, with AAP and IAP of $48 \mathrm{~h}$. In our studies, we found no significant differences in transmission efficiencies of SPCSV by B. afer sensu lato and $\mathrm{B}$. tabaci biotype $\mathrm{B}$ at 20 or $25^{\circ} \mathrm{C}$ when acquired from singly or doubly infected plants. These results were similar to those obtained by Valverde et al. (40), who reported similar transmission rates for a non-EA isolate of SPCSV with $B$. tabaci biotype $\mathrm{B}$ from either single or double infections of SPCSV and SPFMV. It is known from previous reports $(9,14,15,26)$ that SPCSV titers may significantly decrease in double infections with SPFMV. We did not estimate the SPCSV titer in the source plants in single and double infections with SPFMV. However, we observed that the number of SPCSV-infected plants was lower when the virus was transmitted by $B$. afer sensu lato from doubly infected plants than from singly infected plants. This is interesting, and it seems to be in line with the previous reports, suggesting that SPCSV titer was somewhat lower in double infections. Lower transmissions of the Crinivirus spp. ToCV and LIYV by whiteflies were also observed from source plants with lower virus concentration $(27,28,42)$. In our study, the apparent increased rate in the transmission of SPCSV by B. tabaci biotype B from doubly infected plants seems contradictory to that expected with SPVD.

Most whitefly-transmitted viruses are transmitted by a single genus of whitefly. ToCV, a Crinivirus sp. closely related to SPCSV (43), is the best-known exception to this. ToCV has the ability to be transmitted by four whitefly vectors in two genera: B. tabaci biotypes A and B, T. abutiloneus, and $T$. vaporariorum $(41,42,45)$, although efficiency and persistence differ among the vectors (42). In the present study, SPCSV was shown to be transmissible by vectors within both the Bemisia and Trialeurodes genera $(34,40)$. Taking our findings into account, SPCSV, like ToCV, shares the distinction of transmissibility by three different whitefly species (B. tabaci biotype B, B. afer sensu lato, and T. abutiloneus) and, to the best of our knowledge, is the only Crinivirus sp. transmitted by a Bemisia sp. other than B. tabaci. Although we obtained a similar rate of transmission of SPCSV with both species of Bemisia (6.1 to $13.1 \%$, respectively), it was higher than that reported for $T$. abutiloneus (3.2\%) (34). Like other Crinivirus spp., SPCSV is not transmitted mechanically (7); therefore, it is dependent on whiteflies for plant-to-plant dissemination in the field.

The presence of $B$. tabaci biotype B, $B$. afer sensu lato, and $T$. vaporariorum on sweetpotato has been observed on the Peruvian coast. Because attempts to transmit SPCSV with $T$. vaporariorum have been unsuccessful (unpublished data), B. afer sensu lato and $B$. tabaci biotype $\mathrm{B}$ are likely to be the predominant vectors of SPCSV in Peru. Temperature is one of the main environmental factors affecting whitefly population dynamics (23). In the Cañete Valley, B. afer sensu lato predominates in sweetpotato fields after September, accounting for $99 \%$ of the whiteflies in November and December (25). Before September, B. tabaci biotype B is the dominant whitefly species in sweetpotato. The shift in whitefly population structure parallels changes in seasonal temperatures. It suggests that, in the winter and spring seasons (cooler temperatures), B. afer becomes the primary vector for SPCSV in the Cañete Valley, whereas B. tabaci predominates in the summer and fall (25) seasons, when temperatures are warmer, thus facilitating the dissemination of
SPCSV and, subsequently, SPVD all year round.

$B$. hancocki has been synonymized with B. afer (6) but there remains doubt concerning this synonymy (19). The phylogenetic analysis of the nucleotide sequence indicated that $B$. afer sensu lato is different but closely related to $B$. hancocki, $B$. leakii, and B. tuberculata (81.9 to $84.1 \%$ nucleotide identity). This finding is not surprising because the $B$. leakii group is a taxonomically unresolved complex that contains at least three described species: $B$. leakii, B. afer, and B. hancocki (35). The $B$. leakii group is probably more confused than the B. tabaci group (35). The B. leakii group has been reported in India, Fiji, Tahiti, Papua New Guinea, American Samoa, Marshall Islands, Nauru, Palau, Tonga, and Vanuatu; B. hancocki in Africa and southern Europe; and B. tuberculata in Ecuador, Peru, Colombia, Venezuela, Brazil, Nicaragua, Puerto Rico, Costa Rica, and the Dominican Republic. B. tuberculata seems to be the vector of the Begomovirus spp. causing cassava mosaic disease and the agent of the cassava frog skin disease (5). This suggests that species other than B. tabaci can transmit Begomovirus spp.

$B$. afer sensu lato is a newly identified vector of SPCSV, the most important virus component of SPVD, and transmission rates seems to be sufficient to allow for disease spread. Because B. afer sensu lato outnumbers $B$. tabaci biotype B during the cooler season in Peruvian sweetpotato fields, it is likely to be the primary vector of SPCSV during those periods. B. tabaci biotype $\mathrm{B}$ is likely to be the predominant vector during the warmer seasons, when it becomes the predominant species. This observation has important epidemiological consequences for the management of sweetpotato virus diseases in Peru and other areas where both $B$. afer sensu lato and SPCSV are present in sweetpotato crops. The B. afer group exhibits considerable puparial morphological plasticity; therefore, we are referring to this species as $B$. afer sensu lato, because it may not be conspecific with the $B$. afer found in Europe, Africa, and Australia.

\section{ACKNOWLEDGMENTS}

This research was partly funded by the Tropical Whitefly Integrated Pest Management Project, funded by the Department for International Development of the UK (DFID). We thank F. de Mendiburu (Research Informatics Unit at CIP) for support with the statistical analysis of data; L. F. Salazar, C. A. Clark, and R. A. Valverde for critically reviewing this manuscript; and the International Center for Tropical Agriculture for helping in the morphological identification and molecular differentiation of whiteflies species and for providing information on sequences for different whiteflies species as indicated in the Materials and Methods.

\section{LITERATURE CITED}

1. Abad, J. A., Parks, E. J., New, S. L., Fuentes, S., Jester, W., and Moyer, J. W. 2007. First re- 
port of Sweet potato chlorotic stunt virus, a component of sweetpotato virus disease, in North Carolina. Plant Dis. 91:327.

2. Alicai, T., Fenby, N. S., Gibson, R. W., Adipala, E., Vetten, H. J., Foster, G. D., and Seal, S. E. 1999. Occurrence of two serotypes of sweet potato chlorotic stunt virus in East Africa and their associated differences in coat protein and HSP70 homologue gene sequences. Plant Pathol. 48:718-726.

3. Anderson, P., Martin, J., Hernandez, P., and Lagnaoui, A. 2001. Bemisia afer sens. lat. (Homoptera: Aleyrodiadae) outbreak in the Americas. Fla. Entomol. 84:316-317.

4. Aritua, V., Alicai, T., Adipala, E., Carey, E. E., and Gibson, R. W. 1998. Aspects of resistance to sweet potato virus disease in sweet potato. Ann. Appl. Biol. 132:387-398.

5. Bellotti, A. C., Smith L., and Lapointe, S.1999. Recent advances in cassava pest management. Annu. Rev. Entomol. 47:346-370.

6. Bink-Moenen, R. M. 1983. Revision of the African Whiteflies (Aleyrodidae). Monografieen van de Nederlandse Entomologisch Vereninging, Amsterdam, No. 10.

7. Brunt, A. A., Crabtree, K., Dallwitz, M. J., Gibbs, A. J., and Watson, L., eds. 1996. Viruses of Plants: Descriptions and Lists from the VIDE Database. CAB International, Cambridge, UK.

8. Calvert, L. A., Cuervo, M., Arroyave, J. A., Constantino, L. M., Belloti, A., and Frohlich, D. 2001. Morphological and mitochondrial DNA marker analysis of whiteflies (Homoptera: Aleyrodidae) colonizing cassava and beans in Colombia. Ann. Entomol. Soc. Am. 94:512-519.

9. Cuellar, W. J., Tairo, F., Kreuze, J. F., and Valkonen, J. P. T. 2008. Analysis of gene content in Sweet potato chlorotic stunt virus RNA1 reveals the presence of P22 protein RNA silencing suppressor in only few isolates: implications to viral evolution and synergism. J. Gen. Virol. 89:573-582.

10. Gibson, R. W., Mpembe, I., Alicai, T., Carey, E. E., Mwanga, R. O. M., Seal, S. E., and Vetten, H. J. 1998. Symptoms, aetiology and serological analysis of sweet potato virus diseases in Uganda. Plant Pathol. 47:95-102.

11. Gutiérrez, D., Fuentes, S., and Salazar, L. F. 2003. Sweetpotato virus disease (SPVD): distribution, incidence, and effect on sweetpotato yield in Peru. Plant Dis. 87:297-302.

12. Hollings, M., Stone, O. M., and Bock, K. R. 1976. Purification and properties of sweet potato mild mottle, a whitefly-borne virus from sweet potato (Ipomoea batatas) in East Africa. Ann. Appl. Biol. 82:511-528.

13. Hoyer, U., Maiss, E., Jelkmann, W., Lesemann, D. E., and Vetten, H. J. 1996. Identification of the coat protein gene of a sweet potato sunken vein closterovirus isolate from Kenya and evidence for a serological relationship among geographically diverse closterovirus isolates from sweet potato. Phytopathology 86:747-750.

14. Karyeija, R. F., Kreuze, J. F., Gibson, R. W., and Valkonen, J. P. T. 2000. Synergistic interactions of a potyvirus and a phloem-limited crinivirus in sweet potato plants. Virology 269:26-36.
15. Kokkinos, C. D., and Clark, C. A. 2006. Interactions among Sweet potato chlorotic stunt virus and different potyviruses and Potyvirus strains infecting sweetpotato in the United States. Plant Dis. 90:1347-1352.

16. Lagnaoui, A. 2001. The whitefly complex (Homoptera:Aleyrodidae) affecting sweet potato in the Cañete Valle of Peru. International Symposium: Sweet Potato Food and Health for the Future. Sec. BII-O-11.

17. Loebenstein, G., Fuentes, S., Cohen, J., and Salazar, L. F. 2003. Sweet potato. Pages 223248 in: Virus and Virus-like Diseases of Major Crops in Developing Countries. G. Loebenstein and G. Thottappilly, eds. Kluber Academic Publishers, Dordrecht, The Netherlands.

18. Malumphy, C. P. 2003. The status of Bemisia afer (Priesner \& Hosny) in Britain (Homoptera: Aleyrodidae). Entomol. Gaz. 54:191-196.

19. Martin, J. H. 1987. An identification guide to common whitefly pest species of the world (Homoptera, Aleyrodidae). Trop. Pest Manage. 33:298-322.

20. Martin, J. H., Mifsud, D., and Rapisarda, C. 2000. The whiteflies (Hemiptera: Aleyrodidae) of Europe and the Mediterranean basin. Bull. Entomol. Res. 90:407-474.

21. Martin, J. H., and Mound, L. 2007. An annotated check list of the world's whiteflies (Insecta: Hemiptera: Aleyrodidae). Zootaxa 1492:1-84.

22. Maruthi, M. N., Hillocks, R. J., Mtunda, K., Raya, M. D., Muhanna, M., Kiozia, H., Rekha, A. R., Colvin, J., and Thresh, J. M. 2005. Transmission of Cassava brown streak virus by Bemisia tabaci (Gennadius). J. Phytopathol. 153:307-312.

23. Morales, F., and Jones, P. 2004. The ecology and epidemiology of whitefly-transmitted viruses in Latin America. Virus Res. 100:57-65.

24. Mound, L. A., and Halsey, S. H. 1978. Whitefly of the World: A Systematic Catalogue of the Aleyrodidae (Homoptera) with Host Plant and Natural Enemy Data. British Museum (Natural History), Chichester, UK.

25. Mujica, N., Zegarra, O., and Lagnaoui, A. 2002. Ocurrencia estacional de las moscas blancas Bemisia tabaci y Bemisia afer en el Valle de Cañete. Sociedad Entomológica del Perú (SEP). Programa y resúmenes. XLIV Convención Nacional de Entomología.

26. Mukasa, S. B., Rubaihayo, P. R., and Valkonen, J. P. T. 2006. Interactions between a crinivirus, an ipomovirus and a potyvirus in coinfected sweet potato plants. Plant Pathol. 55:458-467.

27. Ng, J. C. K., and Falk, B. W. 2006. Virusvector interactions mediating nonpersistent and semipersistent transmission of plant viruses. Annu. Rev. Phytopathol. 47:183-212.

28. Ng, J. C. K., Tian, T., and Falk, B. W. 2004. Quantitative parameters determining whitefly (Bemisia tabaci) transmission of Lettuce infectious yellows virus and an engineered defective RNA. J. Gen. Virol. 85:2697-2707.

29. Ngeve, J. M., and Bouwkamp, J. C. 1991. Effects of sweet potato virus disease (SPVD) on the yield of sweet potato genotypes in Cameroon. Exp. Agric. 27:221-225.

30. OEPP/EPPO. 2004. EPPO standards PM7/35: diagnostic protocols for regulated pests. EPPO
Bull. 34:281-285.

31. R Development Core Team. 2007. R: A Language and Environment for Statistical Computing. R Foundation for Statistical Computing, Vienna, Austria. http://www.R-project.org.

32. Schaefers, G. A., and Terry, E. R. 1976. Insect transmission of sweet potato disease agents in Nigeria. Phytopathology 66:645-645.

33. Sheffield, F. M. L. 1958. Virus diseases of sweet potato in East Africa: II. Transmission to alternative hosts. Phytopathology 48:1-6.

34. Sim, J., Valverde, R. A., and Clark, C. A. 2000. Whitefly transmission of Sweet potato chlorotic stunt virus. Plant Dis. 84:1250.

35. Stansly, P. A., and McKenzie, C. L. 2007. Fourth International Bemisia Workshop International Whitefly Genomics Workshop. J. Insect Sci. 8:4 (available online: insectscience.org/8.04).

36. Tairo, F., Musaka, S. B., Jones, R. A. C., Kullaia, A., Rubaihayo, P. R., and Valkonen, J. P. T. 2005. Unraveling the genetic diversity of the three main viruses involved in sweet potato virus disease (SPVD), and its practical implications. Mol. Plant Pathol. 6:199-211.

37. Tamura, K., Dudley, J., Nei, M., and Kumar, S. 2007. MEGA4: Molecular evolutionary genetics analysis (MEGA) software version 4.0. Mol. Biol. Evol. 24:1596-1599.

38. Trenado, H. P., Lozano, G., Valverde, R. A., and Navas-Castillo, J. 2007. First report of Sweet potato virus $G$ and Sweet potato virus 2 infecting sweet potato in Spain. Plant Dis. 91:1687.

39. Untiveros, M., Fuentes, S., and Salazar, L. F. 2007. Synergistic interaction of Sweet potato chlorotic stunt virus (Crinivirus) with carla-, cucumo-, ipomo- and potyviruses infecting sweet potato. Plant Dis. 91:669-676

40. Valverde, R. A., Sim, J., and Lotrakul, P. 2004. Whitefly transmission of sweet potato viruses. Virus Res. 100:123-128.

41. Wintermantel, W. M. 2004. Emergence of greenhouse whitefly (Trialeurodes vaporariorum) transmitted Crinivirus as threats to vegetables and fruit production in North America. APSnet feature article June 2004. Online publication.

42. Wintermantel, W. M., and Wisler, G. C. 2006. Vector specificity, host range, and genetic diversity of Tomato chlorosis virus. Plant Dis. 90:814-819.

43. Wintermantel, W. M., Wisler, G. C., Anchieta, A. G., Liu, H.-Y., Karasev, A. V., and Tzanetakis, I. E. 2005. The complete nucleotide sequence and genome organization of $\mathrm{To}$ mato chlorosis virus. Arch. Virol. 150:22872298

44. Wisler, G. C., Duffus, J. E., Liu, H.-Y., and Li, R. H. 1998. Ecology and epidemiology of whitefly-transmitted closteroviruses. Plant Dis. 82:270-280.

45. Wisler, G. C., Li, R. H., Liu, H.-Y., Lowry, D. S., and Duffus, J. E. 1998. Tomato chlorosis virus: a new whitefly-transmitted, phloem limited, bipartite closterovirus of tomato. Phytopathology 88:402-409.

46. Xiong, B., and Kocher, T. D. 1991. Comparison of mitochondrial DNA sequences of seven morphospecies of black flies (Diptera: Simuliidae). Genome 34:306-311. 